\title{
Novel Supported Bimetallic Carbide Catalysts for Coprocessing of Coal with Waste Materials
}

\author{
Semi-Annual Report \\ October 1, 1997 - March 31, 1998
}

S. T. Oyama; D. F. Cox; C. Song; F. Allen

Work Performed Under Contract No.: DE-FG26-97FT97265

\author{
For \\ U.S. Department of Energy \\ Office of Fossil Energy \\ Federal Energy Technology Center \\ P.O. Box 880 \\ Morgantown, West Virginia 26507-0880
}

By

Virginia Polytechnic Institute \& State University

Department of Chemical Engineering

Blacksburg, Virginia 24061-0211

Ames, Iowa 50011-2230 


\section{Disclaimer}

This report was prepared as an account of work sponsored by an agency of the United States Government. Neither the United States Government nor any agency thereof, nor any of their employees, makes any warranty, express or implied, or assumes any legal liability or responsibility for the accuracy, completeness, or usefulness of any information, apparatus, product, or process disclosed, or represents that its use would not infringe privately owned rights. Reference herein to any specific commercial product, process, or service by trade

name, trademark, manufacturer, or otherwise does not necessarily constitute or imply its endorsement, recommendation, or favoring by the United States Government or any agency thereof. The views and opinions of authors expressed herein do not necessarily state or reflect those of the United States Government or any agency thereof. 


\title{
NOVEL SUPPORTED BIMETALLIC CARBIDE CATALYSTS FOR COPROCESSING OF COAL WITH WASTE MATERIALS
}

\author{
Type of report \\ Seminannual \\ Reporting Period: \\ October 1, 1997-March 30, 1998 (First semiannual) \\ Principal Investigators: \\ Date of Report: \\ S. T. Oyama, D. F. Cox, C. Song, F. Allen \\ DOE Award Number: \\ March 30, 1998 \\ DE-FG26-97FT97265 - 01 \\ Institute: \\ Virginia Polytechnic Institute \& State University \\ Department of Chemical Engineering \\ Blacksburg, VA 24061-0211 \\ Grant Date: \\ October 1, 1997 \\ Contracting Officer's Rep: Udaya Rao
}




\title{
NOVEL SUPPORTED BIMETALLIC CARBIDE CATALYSTS FOR COPROCESSING OF COAL WITH WASTE MATERIALS FIRST SEMIANNUAL REPORT
}

\author{
S. Ted Oyama, David F. Cox, Chunshan Song, Fred Allen
}

\section{Disclaimer}

This report was prepared as an account of work sponsored by an agency of the United States Government. Neither the United States Government nor any agency thereof, nor any of their employees, makes any warranty, express or implied, or assumes any legal liability or responsibility for the accuracy, completeness, or usefulness of any information, apparatus, product, or process disclosed, or represents that its use would not infringe privately owned rights. Reference herein to any specific commercial product, process, or service by trade name, trademark, manufacturer, or otherwise does not necessarily constitute or imply its endorsement, recommendation, or favoring by the United States Government or any agency thereof. The views and opinions of authors expressed herein do not necessarily state or reflect those of the United States

\section{Table of Contents}

Title Page

Disclaimer

Table of Contents

Abstract

Introduction

Results and Discussion

Conclusion

References 


\begin{abstract}
The effect of phosphorus on $\mathrm{Mo}_{2} \mathrm{C}$ supported on $\gamma-\mathrm{Al}_{2} \mathrm{O}_{3}$ and activated carbon was studied. The catalysts were characterized by $\mathrm{CO}$ chemisorption, BET surface area measurements, x-ray diffraction (XRD), x-ray photoelectron spectroscopy (XPS), and tested for their reactivity for hydroprocessing reactions, particularly hydrogenation (HYD), hydrodesulfurization (HDS) and hydrodenitrogenation (HDN), using model liquid compounds. The P-containing catalysts had higher reactivity for HDN than those without P. HDS was higher when the $\mathrm{Mo}_{2} \mathrm{C}$ was synthesized on $\gamma-\mathrm{Al}_{2} \mathrm{O}_{3}$ previously treated with $\mathrm{P}$ than when the Mo component and $\mathrm{P}$ were added together on $\gamma-\mathrm{Al}_{2} \mathrm{O}_{3}$. Post reaction characterization indicates that the catalysts were tolerant of sulfur.
\end{abstract}

\title{
Introduction
}

It is well documented that sulfided catalysts with additives are used in hydrotreating reactions such as hydrogenation (HDN), hydrodesulfurization (HDS), hydrodenitrogenation (HDN) and hydrodemetallization (HDM) $[1,2,3]$. Additives such as P have a promotional effect when added to the oxide forms of the catalyst and this effect is typically explained in terms of dispersion of the metal salts on the support, modification of acid sites or formation of a new active phase $[4,5]$. Clearly, little agreement exists in the literature on these effects. In recent years the application of transition metal carbides and nitrides for hydrotreating reactions has been studied in great detail $[6,7,8,9]$. There has also been some work on supported carbides and nitrides $[10,11,12,13]$. However, information available on the effect of additives on transition metal carbide catalysts and their reactivity for hydrotreating reactions is very limited [14]. In this report the synthesis and characterization of $\mathrm{Mo}_{2} \mathrm{C}$ on $\gamma-\mathrm{Al}_{2} \mathrm{O}_{3}$ and an activated carbon support, and the effect of phosphorus additive are reported. The catalysts were synthesized by a temperature programmed reaction method and were characterized by $\mathrm{CO}$ chemisorption, BET surface area measurements, $\mathrm{x}$-ray diffraction (XRD), x-ray photoelectron spectroscopy (XPS) and near-edge X-ray absorption fine structure (NEXAFS). The reactivity of the catalysts for simultaneous hydrogenation (HYD) of quinoline, hydrodenitrogenation (HDN) of quinoline and hydrodesulfurization (HDS) of dibenzothiophene are reported. In addition, post-reaction composition is also discussed.

\section{Results and Discussion}

\section{Characterization}

A summary of the surface properties of the catalysts are given in Table 1. The total surface area of the alumina supported systems is generally slightly smaller than that of the support itself. The exception is the P-treated alumina which shows complete retention of the original surface area. The $\mathrm{P}$ apparently stabilizes the support against sintering at the elevated temperatures of carbide formation.

The XRD patterns of the synthesized catalysts show mostly the features of the support, but the presence of $\beta-\mathrm{Mo}_{2} \mathrm{C}$ (hcp, $\mathrm{P} 63 / \mathrm{mmc}$ ) can also be clearly discerned. The intensity of the $\mathrm{Mo}_{2} \mathrm{C}$ peaks in the $\mathrm{Mo}_{2} \mathrm{C} / \gamma-\mathrm{Al}_{2} \mathrm{O}_{3}-\mathrm{P}$ is higher than the catalyst without $\mathrm{P}$ suggesting that the particle size is larger for the former catalyst, even though the support surface area is larger. This result is consistent with a decreased interaction between $\mathrm{MoO}_{3}$ and $\gamma-\mathrm{Al}_{2} \mathrm{O}_{3}-\mathrm{P}$ likely due to the formation of a $\mathrm{P}$ layer on the support, causing the formation of larger $\mathrm{MoO}_{3}$ grains and consequently larger particles of $\mathrm{Mo}_{2} \mathrm{C}$. This phenomenon of interaction was also observed by Zeuthen et al. [15], who suggested that this was due to the formation of an $\mathrm{AlPO}_{4}$ phase. The dispersions of the $\mathrm{Mo}_{2} \mathrm{C}$ catalysts are compared in Table 1 . It can be seen that the dispersion of 
the $\mathrm{Mo}_{2} \mathrm{C}$ catalysts with $\mathrm{P}$ is lower than the catalyst without any additives. This can again be attributed to the formation of a surface phosphate phase.

Table 1. Characteristics of supported $\mathrm{Mo}_{2} \mathrm{C}$

\begin{tabular}{|l|c|c|c|}
\hline \multicolumn{1}{|c|}{ Catalyst } & CO uptake & Dispersion & $\mathrm{S}_{\mathrm{g}}$ \\
\hline & $\mu \mathrm{mol} \mathrm{g}-1$ & $\%$ & $\mathrm{~m}^{2} \mathrm{~g}^{-1}$ \\
\hline $40 \% \mathrm{Mo}_{2} \mathrm{C}-\mathrm{P} / \gamma-\mathrm{Al}_{2} \mathrm{O}_{3}$ & 40 & 2.9 & 237 \\
\hline $40 \% \mathrm{Mo}_{2} \mathrm{C} / \gamma-\mathrm{Al}_{2} \mathrm{O}_{3}-\mathrm{P}$ & 39 & 2.8 & 271 \\
\hline $40 \% \mathrm{Mo}_{2} \mathrm{C} / \gamma-\mathrm{Al}_{2} \mathrm{O}_{3}$ & 72 & 5.2 & 223 \\
\hline $20 \% \mathrm{Mo}_{2} \mathrm{C} / \mathrm{C}$ & 42 & 6.1 & 300 \\
\hline $\mathrm{Mo}_{2} \mathrm{C}[22]$ & 99 & 2.0 & 42 \\
\hline$\gamma-\mathrm{Al}_{2} \mathrm{O}_{3}$ & - & - & 260 \\
\hline
\end{tabular}

Table 2 gives the atomic composition of fresh $\mathrm{Mo}_{2} \mathrm{C} / \gamma-\mathrm{Al}_{2} \mathrm{O}_{3}$ and $\mathrm{Mo}_{2} \mathrm{C} / \gamma-\mathrm{Al}_{2} \mathrm{O}_{3}-\mathrm{P}$ catalysts from XPS analysis without any pretreatment to remove the passivation layer.

Table 2. Atomic composition of supported $\mathrm{Mo}_{2} \mathrm{C}$

\begin{tabular}{|l|l|l|l|l|l|l|}
\hline Catalyst & $\mathrm{O}$ & $\mathrm{C}$ & $\mathrm{Mo}$ & $\mathrm{Al}$ & $\mathrm{P}$ & $\mathrm{S}$ \\
\hline fresh $\mathrm{Mo}_{2} \mathrm{C} / \gamma-\mathrm{Al}_{2} \mathrm{O}_{3}$ & 56 & 14 & 5.8 & 24 & 0 & 0 \\
\hline spent $\mathrm{Mo}{ }_{2} \mathrm{C} / \gamma-\mathrm{Al}_{2} \mathrm{O}_{3}$ & 43 & 30 & 4.3 & 20 & 0 & 2.0 \\
\hline fresh $\mathrm{Mo}_{2} \mathrm{C} / \gamma-\mathrm{Al}_{2} \mathrm{O}_{3}-\mathrm{P}$ & 58 & 15 & 5.4 & 20 & 1.5 & 0 \\
\hline spent $\mathrm{Mo}_{2} \mathrm{C} / \gamma-\mathrm{Al}_{2} \mathrm{O}_{3}-\mathrm{P}$ & 43 & 30 & 4.3 & 18 & 2.7 & 2.0 \\
\hline
\end{tabular}

In the case of $\mathrm{Mo}_{2} \mathrm{C} / \gamma-\mathrm{Al}_{2} \mathrm{O}_{3}$, the atomic concentration of $\mathrm{C}$ is $14 \%$, of which $15 \%$ is carbidic carbon (BE of $282.5 \mathrm{eV}$ ) and $85 \%$ is graphitic carbon (by deconvolution). The atomic concentration of Mo is $5.8 \%$ which was deconvoluted to yield $25.2 \% \mathrm{Mo}_{2} \mathrm{C}$ and $74.8 \% \mathrm{MoO}_{3}$ and $\mathrm{MoO}_{2}$. For all the carbide catalysts, it was found that $\mathrm{P}$ is in a highly oxidized state $(\mathrm{PV})$. The atomic composition of the catalysts did not noticeably differ with the addition of $\mathrm{P}$. The atomic concentration of $\mathrm{C}$ is $15 \%$ which was deconvoluted to yield $17.7 \%$ carbidic carbon and $83.3 \%$ graphitic carbon. The atomic concentration of Mo is $5.4 \%$ of which $22.7 \%$ is $\mathrm{Mo}_{2} \mathrm{C}$ and $77.3 \%$ is $\mathrm{MoO}_{3}$ and $\mathrm{MoO}_{2}$.

\section{Reactivity}

The hydrotreating reactions were carried out at $643 \mathrm{~K}$ and $3.1 \mathrm{MPa}$ and the activity of the catalysts are compared to a commercial Ni-Mo-S/Al ${ }_{2} \mathrm{O}_{3}$ catalyst (Shell 324) and unsupported $\mathrm{Mo}_{2} \mathrm{C}$ catalyst. Table 3 provides a summary of the steady state reactivities in terms of conversion and turnover rates (TOR) for HDN and HDS, based on equal number of surface metal atoms (corresponding to $70 \mu \mathrm{mol}$ ) loaded in the reactor. The amount of reference catalyst Ni-Mo- 
$\mathrm{S} / \mathrm{Al}_{2} \mathrm{O}_{3}$ used in the reaction was $140 \mu \mathrm{mol}$ (based on $\mathrm{O}_{2}$ chemisorption). The HDN TOR of the catalysts with $\mathrm{P}$ added to the support is higher than the reference sulfide catalyst, and both supported and unsupported $\mathrm{Mo}_{2} \mathrm{C}$ catalyst. A similar positive effect of $\mathrm{P}$ additive for the HDN reaction was observed by Eijisbouts et al. [16] and Robinson et al. [17]. In addition, the catalyst with $\mathrm{P}$ co-impregnated on the support has slightly higher HDN activity than the catalyst synthesized on a $\mathrm{P}$ treated $\gamma-\mathrm{Al}_{2} \mathrm{O}_{3}$. The $\mathrm{Mo}{ }_{2} \mathrm{C} / \mathrm{C}$ has a higher activity than the $\mathrm{Mo}_{2} \mathrm{C} / \gamma-\mathrm{Al}_{2} \mathrm{O}_{3}$ catalyst. The products from quinoline HDN were hydrogenated (HYD) quinoline compounds (1, 2, 3, 4-tetrahydroquinoline, 5, 6, 7, 8-tetrahydroquinoline and o-propylaniline) and hydrodenitrogenated hydrocarbons (propylcyclohexane and propylbenzene).

Table 3. Summary of reactivity of supported $\mathrm{Mo}_{2} \mathrm{C}$

\begin{tabular}{|l|c|c|c|c|c|}
\hline \multicolumn{1}{|c|}{ Catalyst } & HYD & HDN & HDS & HDN TOR & HDS TOR \\
\hline & $\%$ & $\%$ & $\%$ & $/ 10^{-3} \mathrm{~s}^{-1}$ & $/ 10^{-3} \mathrm{~s}^{-1}$ \\
\hline $\mathrm{Mo} 2 \mathrm{C}-\mathrm{P} / \gamma-\mathrm{Al}_{2} \mathrm{O}_{3}$ & 29 & 64 & 48 & 1.5 & 0.72 \\
\hline $\mathrm{Mo}_{2} \mathrm{C} / \gamma-\mathrm{Al}_{2} \mathrm{O}_{3}-\mathrm{P}$ & 28 & 57 & 80 & 1.3 & 1.2 \\
\hline $\mathrm{Mo}_{2} \mathrm{C} / \gamma-\mathrm{Al}_{2} \mathrm{O}_{3}$ & 45 & 33 & 65 & 0.76 & 0.98 \\
\hline $\mathrm{Mo}_{2} \mathrm{C} / \mathrm{C}$ & 29 & 49 & 65 & 1.1 & 0.98 \\
\hline $\mathrm{NiMoS} / \mathrm{Al}_{2} \mathrm{O}_{3}[22]$ & 47 & 38 & 79 & 0.46 & 0.62 \\
\hline $\mathrm{Mo}_{2} \mathrm{C}[22]$ & 39 & 47 & 43 & 1.1 & 0.65 \\
\hline
\end{tabular}

The steady state conversion and TOR of the catalysts for HDS of dibenzothiophene are compared in Table 3. Biphenyl was the only product detected (product distribution at steady state is $100 \%$ biphenyl) from dibenzothiophene HDS. From Table 3 it can be seen that the HDS TOR of the supported $\mathrm{Mo}_{2} \mathrm{C}$ catalysts are higher than the reference sulfide catalyst and unsupported $\mathrm{Mo}_{2} \mathrm{C}$. In addition, the TOR of $\mathrm{Mo}_{2} \mathrm{C} / \gamma-\mathrm{Al}_{2} \mathrm{O}_{3}-\mathrm{P}$ is the highest when compared to other catalyst, clearly indicating a positive effect of $\mathrm{P}$ pretreatment on the $\gamma-\mathrm{Al}_{2} \mathrm{O}_{3}$ support. A similar positive effect of $\mathrm{P}$ on the support for sulfided catalysts for HDS reactions was observed by Prada Silvy et al. [18] . Comparing the TOR for the two P containing catalysts indicates that the method of $\mathrm{P}$ inclusion is also important because the TOR of the $\mathrm{Mo}_{2} \mathrm{C}-\mathrm{P} / \gamma-\mathrm{Al}_{2} \mathrm{O}_{3}$ is significantly lower than the $\mathrm{Mo}_{2} \mathrm{C} / \gamma-\mathrm{Al}_{2} \mathrm{O}_{3}$ and $\mathrm{Mo}_{2} \mathrm{C} / \mathrm{C}$ catalysts. In none of the catalysts was there an indication of phosphide formation.

\section{Post-reaction Characterization}

The catalysts were characterized by XRD after the hydroprocessing reactions. The bulk $\mathrm{Mo}_{2} \mathrm{C}$ structure did not change for any of the catalysts during reaction, indicating they are tolerant of sulfur. Table 2 gives the comparison of atomic composition of elements from XPS analysis of the fresh and spent catalysts. The results show that the total S content is only $2 \%$, and this again clearly indicate that the catalysts are tolerant to sulfur for hydrotreating reactions. 


\section{Conclusions}

New catalysts with $\mathrm{P}$ additive were synthesized by temperature programmed reaction, characterized by CO chemisorption, surface area measurements, XRD, XPS, and tested for hydrogenation, hydrodenitrogenation and hydrodesulfurization reactions. The activity of the catalysts was higher when compared to Ni-Mo-S/Al $2 \mathrm{O}_{3}$ (Shell 324), and the catalysts were tolerant of sulfur. The increase in the reactivity of the P treated catalyst can be explained on the basis of a reduced support-metal oxide interaction.

\section{References}

1. Bouwens, S. M. A. M., van der Kraan, A. M., De Beer, V. H. J., and Prins, R., J. Catal. 128, 559 (1991).

2. Muralidhar, G., Massoth, F. E., and Shabtai, J., J .Catal. 85, 44 (1984).

3. Atanasova, P., Halachev, T., Uchyil, J., and Kraus, M., Appl. Catal. 38, 235 (1988).

4. Topsfe, H., Clausen, B. S., and Massoth, F. E., Hydrotreating Catalysis, Springer, 1996.

5. Kraus, H., and Prins, R., J. Catal. 164, 251 (1996).

6. Lee, J. S., Yeom, M. H., Park, K. Y., Nam, I. -S., Chung, J. S., Kim, T. G., and Moon, S. H., J. Catal. 128, 126 (1991).

7. Lee, J. S., Locatelli, S., Oyama, S. T., and Boudart, M., J. Catal. 125, 157 (1990).

8. Lee, J. S., Oyama, S. T., and Boudart, M., J. Catal., 106, 125 (1987).

9. Ramanathan, S., and Oyama, S. T., J. Phys. Chem. 99, 16365 (1995).

10. Abe, H., Cheung, T., and Bell, A. T., Catal. Lett. 21, 11 (1993).

11. Colling, C. W., and Thompson, L. T., J. Catal. 146, 193 (1994).

12. Pham-Huu, C., Del Gallo, P., Peschiera, E., and Ledoux, M. J., Appl. Catal. A 132, 77 (1995).

13. Lee, J. S., Lee, K. H., and Lee, J. Y., J. Phys. Chem. 96, 362 (1992).

14. Sellem, S., Potvin, C., Manoli, J. M., Contant, R., and Djega-Mariasassou, G., J. Chem. Soc., Chem. Commun., 359 (1995).

15. Zeuthen, P., Blom, P., Muegge, B., and Massoth, F. E., Appl. Catal. 68, 117 (1991).

16. Eijsbouts, S., van Gestel, J. N. M., van Veen, J. A. R., de Beer, V. H. J., and Prins, R., J. Catal., 131, 412 (1991).

17. Robinson, W. R. A. M., van Gestel, J. N. M., Koranyi, T. I., Eijsbouts, S., van der Kraan, A. M., van Veen, J. A. R., and de Beer, V. H. J., J. Catal., 161, 539 (1996).

18. Prada Silvy, R., Romero, Y., Guaregua, J., and Galiosso, R., Preparation of Catalysts V, Eds. Poncelet, G., Jacobs, P. A., Grange, P., and Delmon, B. Elsevier Science Publishers, Amsterdam, 1991. 